Volume 2 No. 2, Desember 2017

P ISSN 2442-594X | E ISSN 2579-5708

http://journal.iainlangsa.ac.id/index.php/tibyan

\title{
PERKEMBANGAN TAFSIR FALSAFI DALAM RANAH PEMIKIRAN ISLAM
}

Development Of The Philosophical's Interpretation In the Realm of Islamic's Thought

\author{
Syafieh \\ Institut Agama Islam Negeri Langsa \\ syafiehyanti@gmail.com
}

\begin{abstract}
Abstrak
This article explain about the development of philosophical interpretation from classical to modern era. The emergence of the medieval philosophical interpretation has provided a new insight into the development of interpretation. The existence of this style of philosophical interpretation is also the "gateway" of the advancement of thought in Islam. In the modern century came a new method of interpretation with a philosophical approach that is hermeneutic discourse. In the study, hermeneutical methods contain hermeneutical circles that should not be excluded one of them, namely text (text), author or author (outhor), and reader (reader) with text, context and contextualization. However, the discourse of hermeneutics has contributed greatly to the development of interpretive thought in the Islamic world. When hermeneutics is practiced in Islam. Hermeneutic interpretation not only understands the meaning of the Qur'anic text as God's word or context, but also on how the interpretation of the Qur'an as the spirit of the Muslim community to change its society for the better and the best.
\end{abstract}

Keywords: Philosophical Interpretation, Qur'an, Hermeneutic of the Qu'ran

\begin{abstract}
Abstrak
Artikel ini menjelaskan tentang perkembangan tafsir falsafi dari era klasik ke era modern. Munculnya tafsir falsafi abad pertengahan telah memberikan wawasan baru ke dalam pengembangan tafsir. Keberadaan gaya tafsir falsafi ini juga merupakan "gerbang" dari kemajuan pemikiran dalam Islam. Pada abad modern muncul metode penafsiran baru dengan pendekatan filosofis yaitu wacana hermeneutika. Dalam penelitian, metode hermeneutik mengandung lingkaran hermeneutik yang tidak boleh dikesampingkan salah satunya, yaitu teks (teks), penulis atau penulis (outhor), dan pembaca (reader) dengan teks, konteks dan kontekstualisasi. Namun, wacana hermeneutika telah banyak berkontribusi pada perkembangan pemikiran Tafsir di dunia Islam. Ketika hermeneutika dipraktekkan dalam Islam. Tasir Hermeneutik tidak hanya memahami makna teks Alquran sebagai kata atau konteks Tuhan, tetapi juga bagaimana interpretasi AlQuran sebagai semangat komunitas Muslim untuk mengubah masyarakatnya menjadi lebih baik dan terbaik
\end{abstract}

Kata Kunci: Tafsir Falsafi, Alquran, Hermeneutika Alquran 


\section{Pendahuluan}

Pekembangan penafsiran terus berkembang mulai dari wafatnya Nabi Muhammad saw. Dimulai pada periode Islam klasik kemudian periode pertengahan dan terus berkembang sampai masa modern-kontemporer. Pada masa pertengahan, muncul berbagai corak penafsiran seiring dengan perkembangan ilmu pengetahuan yang ada. Dengan perkembangan ilmu pengetahuan itu juga membuat penafsiran semakin berwarna. Tafsir pada masa ini lebih terbagi-bagi dalam berbagai corak atau nuansa khusus yang memberikan warna tersendiri terhadap tafsir. Salah sat unya adalaha tafsir yang bercorak falsafat atau yang lebih dikenal dengan tafsir falsafi.

Secara historis, keberadaan tafsir tidak bisa lepas dari terjadinya kontak dunia Islam dengan pemikiran filsafat Yunani. Pemikiran filosofis masuk ke dalam Islam melalui filsafat Yunani yang dijumpai oleh ahli-ahli fikir Islam di Suria, Mesopotamia, Persia, Persia, dan Mesir. Kebudayaan dan filsafat Yunani datang ke daerah-daerah itu dengan ekspansi Alexander yang Agung ke Timur di abad keempat sebelum Kristus. Politik Alexsander untuk menyatukan kebudayaan Yunani dan Persia meninggalkan bekas besar di daerah-daerah yang pernah dikuasainya dan kemudian timbullah pusatpusat kebudayaan Yunani di Timur, seperti Alexsandria di Mesir, Antioch di Suria, Jundisyapur di Mesopotamia dan Basra di Persia. ${ }^{1}$

Akhir-akhir ini di kalangan kaum muslimin - terutama kaum modernis - telah banyak memanfaatkan Hermeneutika sebagai salah satu instrumen untuk menggali isi dan kandungan Alquran. Kecendrungan kalangan muslim modernis menjadikan Hermeneutika ${ }^{2}$ sebagai pengganti ilmu tafsir dalam memahami Alquran telah merabah begitu luas. Kalangan muslim modernis mempunyai asumsi bahwa ketika kita menerapkan metode hermeneutika kepada Alquran, kita akan menemukan nilai-nilai yang tinggi dan agung. ${ }^{3}$ Dengan hermeneutika, menunjukkan mu'jizat Alquran dalam tatanan sosial dan kemasyarakatan.

Penggunaan hermeneutika dalam dunia penafsiran Alquran adalah hal baru yang belum pernah dilakukan oleh para mufassir terdahulu. Dalam tradisi keilmuwan Islam telah dikenal ilmu tafsir yang berfungsi untuk menafsirkan Alquran, sehingga ilmu ini dianggap telah mapan dalam bidangnya. Dari segi epistemologi dan metodologi ilmu ini telah diakui mampu mengembankan tugasnya untuk menggali kandungan Alquran. Namun pada abad modern ini, muncullah mufassir yang mewarnai dalam perkembangan tafsir di kalangan umat Islam. Bebebrapa cendikiawan muslim seperti Nashr Hamid Abu Zayd, al-Khuli, Syahrur dan sebagainnya adalah mufassir yang berani memunculkan metode dan pendekatan baru alquran.

Penggunaan hermeneutika dalam penafsiran Alquranmendapat tanggapan yang beragam dari para ulama dancendekiawan Muslim. Ada yang menyetujuinya dan ada pula yangmenolaknya. Hal itu karena hermeneutika memang tergolongbaru dalam

\footnotetext{
${ }^{1}$ Abdul Mustaqim, Dinamika Sejarah Tafsir Al-Quran, (Yogyakarta: Adab Press, 2012), h.132

${ }^{2}$ Mircea Eliade, The Encyclopedia of Religion, (New York: Macmillan, 1993), h. 279

${ }^{3}$ Lihat Slamet Muliono R, "Hermeneutika Alquran: Antara Pemaknaan Tekstual dan Kontekstual", dalam, Ulumuna, Volume XIV Nomor 1 Juni 2010, h. 101-120
} 
khazanah tafsir Alquran. Namun di tengah pro dankontra, metode yang sejatinya merupakan bagian dari kajianfilsafat ini tetap mengalami perkembangan signifikan di tanganpara hermeneut (pengaplikasi hermeneutika) Muslimkontemporer. Tulisan ini akan memaparkan tentang perkembangan tafsir falsafi dari masa klasik sampai modern.

\section{Munculnya Tafsir Falsafi \\ Pengertian Tafsir Falsafi}

Berbicara awal munculnya Tafsir Falsafi ini jika dirunut ke belakang sampai pada masa sahabat, bisa dikatakan bahwa bibit kemunculannya dimulai oleh 'Abdullah bin Mas'ud yang dikenal dengan keluwesan kecerdasannya terutama dalam hal ijtihad (ra'y). Dan hal lain yang bisa menguatkan hal tersebut adalah bahwa ia tinggal/ditugaskan di Irak yang penduduknya memiliki olah pikir yang sangat luar biasa. Pertimbangan selanjutnya diketahui bahwa corak tafsir ini tampak jelas pada masa Bani Abbasiah yang notabenenya juga berpusat di Irak (tempat Ibn Mas'ud bertugas untuk mengajarkan agama Islam).

Menurut Quraish Shihab, pengertian tafsir falsafi adalah upaya penafsiran Alquran dikaitkan dengan persoalan-persoalan filsafat. ${ }^{4}$ Tafsir falsafi yaitu tafsir yang didominasi oleh teori-teori filsafat sebagai paradigmanya. Ada juga yang mendefisnisikan tafsir falsafi sebagai penafsiran ayat-ayat Alquran dengan menggunakan teori-teori filsafat. Hal ini berarti bahwa ayat-ayat Alquran dapat ditafsirkan dengan menggunakan filsafat. Karena ayat Alquran bisaberkaitan dengan persoalan-persoalan filsafat atau ditafsirkan dengan menggunakan teori-teori filsafat.

Tafsîr al-Falâsifah, yakni menafsirkan ayat-ayat Alquran berdasarkan pemikiran atau pandangan falsafi, seperti tafsir bi al-Rayi. Dalam hal ini ayat lebih berfungsi sebagai justifikasi pemikiran yang ditulis, bukan pemikiran yang menjustifikasi ayat. ${ }^{5}$ seperti tafsir yang dilakukan al-Farabi, ibn Sina, dan ikhwan al-Shafa. Menurut Dhahabi, tafsir mereka ini di tolak dan di anggap merusak agama dari dalam. ${ }^{6}$

Alquran adalah sumber ajaran dan pedoman hidup umat Islam yang pertama, kitab suci ini menempati posisi sentral dalam segala hal yaitu dalam pengembangan dan perkembangan ilmu pengetahuan dan keislaman. Pemahaman ayat-ayat Alquran melalui penafsiran mempunyai peranan yang sangat besar bagi maju mundurnya peradaban umat Islam. Di dalam menafsirkan Alquran terdapat beberapa metode yang dipergunakan sehingga membawa hasil yang berbeda-beda pula, sesuai dengan sudut pandang dan latar belakang masing-masing mufasir. Sehingga timbullah berbagai corak penafsiran seperti tafsir shufi, ilmi, adabi, fiqhi, falsafi dan lain-lain yang tent unya juga akan menimbulkan pembahasan yang luas serta pro-kontra dari zaman ke zaman.

Penafsiran terhadap Aquran telah tumbuh dan berkembang sejak masa awal Islam. Sejalan dengan kebutuhan umat Islam untuk mengetahui seluruh segi kandungan

\footnotetext{
${ }^{4}$ Lihat Quraish Shihab dkk, Sejarah dan Ulum Al Qur'an, (Jakarta: Pustaka Firdaus, 1999), h. 182

${ }^{5}$ Muhammad Husein al-Dzahabi, Kitâb al-Tafsîr wa al-Mufassirûn, (Beirut: Dar al-Fikr, 1995), Jilid I, h. 419

${ }^{6}$ Lihat Al-Dzahabi, Kitâb al-Tafsîr wa al-Mufassirûn, h. 431
} 
Alquran serta intensitas perhatian para ulama terhadap tafsir, maka tafsir Alquran pun terus berkembang, baik pada masa ulama salaf maupun khalaf bahkan hingga sekarang. Pada tahapan-tahapan perkembangannya tersebut, muncullah karakteristik yang berbeda-beda baik dalam metode maupun corak penafsirannya.

Sejarah telah mencatat perkembangan tafsir yang begitu pesat, seiring dengan kebutuhan, dan kemampuan manusia dalam menginterpretasikan ayat-ayat Tuhan. Setiap karya tafsir yang lahir pasti memiliki sisi positif dan negatif, demikian juga tafsir falsafi yang cenderung membangun proposisi universal hanya berdasarkan logika dan karena peran logika begitu mendominasi, maka metode ini kurang memperhatikan aspek historisitas kitab suci. Namun begitu, tetap ada sisi positifnya yaitu kemampuannya membangun abstraksi dan proposisi makna-makna latent (tersembunyi) yang diangkat dari teks kitab suci untuk dikomunikasikan lebih luas lagi kepada masyarakat dunia tanpa hambatan budaya dan bahasa. ${ }^{7}$

Dari pemahaman tersebut tidak terlalu berlebihan kiranya kalau kita mengharapkan nantinya terwujudnya tafsir falsafi ideal, sebuah konsep tafir falsafi yang kontemporer yang tidak hanya berlandaskan interpretasi pada kekuatan logika tetapi juga memberikan perhatian pada realitas sejarah yang mengiringinya. Sebab pada prinsipnya teks Alquran tidak lepas dari struktur historis dan konteks sosiokultural di mana ia diturunkan. Dengan demikian, akan lahir tarfir-tafsir filosofis yang logis dan proporsional, tidak spekulatif dan diberlebih-lebihan. Dan mungkin harapan tersebut tidak terlalu berlebihan karena di samping memang kita belum menemukan tafsir yang secara utuh menggunakan pendekatan filosofis, kalaupun ada itu hanya pemahaman beberapa ayat yang bisa kita temukan dalam buku-buku mereka.

Corak penafsiran ini akan sangat bermanfaat nantinya untuk membuka khazanah keislaman kita, sehingga kita nantinya akan mampu mengetahui maksud dari ayat tersebut dari berbagai aspek, terutama aspek filsafat. Metode berfikir yang digunakan filsafat yang bebas, radikal dan berada dalam dataran makna tentunya akan memperoleh hasil penafsiran yang lebih valid walaupun keberannya masih tetap relatif.

Namun kombinasi hasil penafsiran tersebut dengan aspek sosio-historis tentunya akan semakin menyempurnakan eksistensinya. Sehingga produk tafsir ini jelas akan lebih memikat dan kredibel dari pada tafsir lain.

\section{Sejarah Munculnya Tafsir Falsafi}

Pada saat ilmu-ilmu agama dan sain mengalami kemajuan, kebudayaankebudayaan Islam berkembang di wilayah-wilayah kekuasaan Islam dan penerjemahan buku-buku asing ke dalam bahasa Arab digalakkan pada masa khalifah Abbasiyah, diantara buku-buku yang diterjemahkan adalah buku-buku karangan para filosof seperti

${ }^{7}$ Komaruddin Hidayat, Memahami Bahasa Agama, Sebuah Kajian Hermeneutik, (Jakarta: Paramadina, 1996), h. 215 
Aristoteles dan Plato. Pada perkembangan selanjutnya para ulama tafsir mencoba memahami Alquran dengan metode filsafat tersebut, maka lahirlah metode falsafi. ${ }^{8}$

Thaba' Thaba'i dalam tafsir al-Mizan fi tafsir Alquran berpendapat bahwa para filosof menggunakan pemikiran filsafat dalam memahami ayat-ayat Alquran. Sesuai dengan kecenderungan dan keilmuannya, Diantara tokoh filosof Islam adalah AlFarabi, Ibnu-Shina. Thaba' Thaba'i dalam tafsirnya memasukkan pembahasan filsafat sebagai tambahan dalam menerangkan suatu ayat atau menolak teori filsafat yang bertentangan dengan Alquran. Ia menggunakan pembahasan filsafat hanya pada bagian ayat tertentu saja. ${ }^{9}$

Dalam menyikapi interfensi filsafat Yunani dalam proses penafsiran Alquran, umat Islam terbagi menjadi dua golongan yaitu sebagai berikut:

Pertama, Golongan yang menolok filsafat, karena mereka menemukan adanya pertentangan antara filsafat dan agama. Kelompok ini secara radikal menentang filsafat dan berusaha menjauhkan umat darinya. Tokoh pelopor kelompok ini adalah Imam alGhazali, karena itu ia mengarang "tahafut alfalasifah" menyebut mereka dengan istilah kaum bid'ah. Menurutnya mereka membangga-banggakan diri dengan anggapan bahwa mereka akan terhormat jika mereka tidak menerima kebenaran secara taqlid, meskipun sebaliknya mereka justru menerima kebobongan tanpa kritik. ${ }^{10} \mathrm{Al}-\mathrm{Gazali}$ sebenarnya tidak melarang menggunakan pendekatan filosofis. Yang ia tidak sukai dan kritik ialah pendekatan model metafisika spekulatif Ibn Sina dan para filosuf lain yang sama. Namun ia tidak melarang untuk belajar logika, tabi'iyat, matematika dan yang lainnya. ${ }^{11}$

Demikian pula Fakhr al-Razi di dalam kitab tafsirnya mengemukakan paham mereka dan membatalkan teori-teori filsafat mereka karena dinilai bertentangan dengan agama dan Alquran. Dia membeberkan ide-ide filsafat yang dipandang bertentangan, khususnya dengan Alquran dan akhirnya ia menolak dengan tegas berdasarkan alasan dan dalil yang ia anggap memadai. ${ }^{12}$

Kedua, Golongan yang mengagumi dan menerima filsafat meskinya didalamnya terdapat ide-ide yang bertengan dengan nash-nash syar'i. Kelompok ini berupaya mengkompromikan antara filsafat dan agama serta berusaha untuk menyingkapkan segala pertentangan tersebut, namun usaha mereka belum mencapai titik temu secara final, melainkan masih berupaya memecahkan masalah secara setengah-setengah, sebab penjelasan mereka tentang ayat-ayat Alquran semata-mata berangkat dari sudut

\footnotetext{
${ }^{8}$ Abdul Hayy Al-Farmawi, Metode Tafsir Maudhu'i Dan Cara Perepannya, Penerjemah, Suryan A. Jamrah, (Jakarta: PT Raja Grafindo Persada, 1994), h. 20

${ }^{9}$ Lihat Muhammad Hussain At-Thaba'-Thaba'I, al-Mizan fi Tafsir Alquran. (Bairut: Mu,assisah alAlamy Li al Mathbu'at, t.t) h. 3

${ }^{10}$ Lihat Imam Al-Gazāil, Tahāfut al-Falāsifah (kerancuan para filosof), diterjemahkan Ahmadie Thaha (Jakarta: Pustaka Panjimas, 1986)., h.13

${ }^{11}$ LihatAl-Gazāli, al-Munqìd min al-Dalāl, (Qahirah: Maktabah al-Islamiyah, 1303 H)., h. 13.

${ }^{12}$ Muhammad Husein al-Dzhabi, At-Tafsir wa Al-Mufassirun, (Bairut: Dar al-Fikri, 1995), Juz III, h. 83
} 
pandang teori filsafat yang didalamnya banyak hal tidak mungkin diterapkan dan dipaksakan terhadap nash-nash Alquran. ${ }^{13}$

Menurut Żahabi, tidak seorang pun dari filosof-filosof Islam yang menerima pemikiran Yunani tersebut yang menulis tafsir secara utuh, dalam artian merka hanya menafsirkan ayat-ayat tertentu dalam Alquran yang berhubungan dengan teori filsafat yang tertuang dalam karya filsafat mereka. ${ }^{14}$

Jadi sederhananya adalah ada dua alasan dalam mengkompromikan Alquran dengan filsafat, yaitu:

a. Cara pertama, mereka melakukan ta'wil terhadap nash-nash Alquran sesuai dengan pandangan filosof. Yakni mereka menundukkan nash-nash Alquran pada pandangan-pandangan filsafat. Sehingga keduanya nampak seiring sejalan.

b. Cara kedua, adalah mereka menjelaskan nash-nash Alquran dengan pandangan pandangan teori filsafat. Mereka menempatkan pandangan para filosof sebagai bagian primer yang mereka ikuti, dan menempatkan Alquran sebagai bagian sekunder yang mengikuti filsafat. Yakni filsafat melampaui Alquran. Cara ini lebih berbahaya dari cara yang pertama. ${ }^{15}$

Contoh Tafsir Falsafi adalah seperti dikatan al-Dzahabi menyebutkan penafsiran sebagian filosof yang mengingkari kemungkinanmi'raj Nabi Muhammad Saw., dengan fisik di sampingruhnya.Merekahanya meyakini kemungkinanmi'raj Nabi Muhammad Saw., hanya dengan ruh tanpa jasad.

Di antara kitab tafsir yang ditulis berdasakan corak falsafi ini, yaitu dari golongan pertama yang menolak tafsir falsafat adalah:

1) Mafatih Al-Ghaib, karya Fakhr al-Razi (w. $606 \mathrm{H}$ )

2) Al-Isyarat, karya Imam al-Ghazali (w. $505 \mathrm{H}$ )

Sedangkan dari golongan kedua seperti komentar al-Dzahabi tidak pernah mendengar bahwa diantara filosof mengarang kitab tafsir Alquran secara lengkap, kerana sejauh ini tidak lebih dari sebagian pemahaman terhadat Alquran secara parsial yang termuat dalam kitab falsafah yang mereka tulis. ${ }^{16}$ Penulisan secara parsial tafsir falsafi antara lain:

1) Fushush al-Hikam, karya al-Farabi (w. 339 H)

2) Rasail Ibn Sina, karya Ibn Sina (w. 370 H)

3) Rasail Ikhwan al-Safa. ${ }^{17}$

\section{Karakteristik Tafsir Falsafi}

karakter dari corak tafsir falsafi adalah penggunaan ilmu filsafat sebagai penafsiran Alquran. Cara yang ditempuh adalah dengan mena'wil teks-teks agama dan

\footnotetext{
${ }^{13}$ Muhammad Husain Al Żahabi, Tafsir wa al-Mufassirūn (Mesir: Dar al-Kuttab, 1976)., h. 419.

${ }^{14} \mathrm{Al}$ Żahabi, Tafsir wa al-Mufassirūn, h. 421

${ }^{15}$ Mahmud Hamdi, Al-Mausu'ah Alquraniah al Mutakhossishoh, (Kairo: Kementrian wakaf, 2003), h. 285

${ }^{16} \mathrm{Al}$ Żahabi, Tafsir wa al-Mufassirūn, h. 421

${ }^{17}$ Lihat Al-Majlis al-A'la li al-Syuuni al-Islamiyah, al-Mausuah Alquraniyah al-Mutakhossisah, (Kairo: Wazir al-Auqaf, 2003), h. 285-286.
} 
hakikat hukumnya yang sesuai dengan pandangan-pandangan filsosofi. Ini berarti bahwa pemaknaan teks Alquran tunduk kepada pandangan filosof. Selain itu juga menggunakan metode pensyarahan teks-teks agama dan hakikat hukumnya berdasarkan pandangan-pandangan filosof. ${ }^{18}$

Di dalam corak tafsir ini, berbagai aliran filsafat menjadi variabel penting di dalam menafsirkan Alquran. Pengertian filsafat tidak hanya membahas tentang metode berfirkir saja, melainkan lebih dari itu filsafat telah menjadi disiplin ilmu yang membicarakan persoalan hubungan manusia dengan Tuhan dan keberadaan Tuhan.

Ranah nuansa tafisr filsafat adalah mengungkap pandangan Alquran secara komprehensif tentang keyakinan dan sistem teologi. Namun, proses yang dilakukan bukan dalam rangka pemihakan terhadap madzhab tertentu, yang sudah terbangun mapan dalam sejarah, tetapi lebih pada upaya menggali secara serius bagaimana Alquran berbicara dalam soal-soal teologis itu dengan melacak tema-tema pokok, serta konteks-konteks di mana terma itu dipakai Alquran.

Muhammad Husain al-Dzahabi menyebutkan bahwa sebenarnya tidak ditemukan adanya ahli filsafat muslim yang menulis tafsir Alquran secara lengkap. Yang ada hanyalah pendapat-pendapat dari tokoh-tokoh mereka yang menafsirkan Alquran secara terpisah dan dikemukakan dalam buku-buku filsafat karangan mereka. ${ }^{19}$

\section{Tokoh-tokoh Tafsir Falsafi dan Tafsirnya}

\section{Ibn Sina (w. $370 \mathrm{H})$}

Karya tafsir Ibn Sina adalah 'Rasail Ibn Sina'. Metode Ibn Sina dalam menafsirkan Alquran adalah dengan memandang Alquran dan filsafat, kemudian menafsirkan Alquran secara filsafat murni. Misalnya dia jelaskan kebenaran-kebenaran agama ditinjau dari tinjauan filsafat. Karena menurutnya Alquran itu sebagai symbol yang sulit dipahami oleh orang-orang awam dan hanya bisa dipahami oleh orang-orang tertentu.

Salah satu ayat yang ditafsirkan oleh Ibn Sina adalah surah al-Haqqah [69] ayat 17:

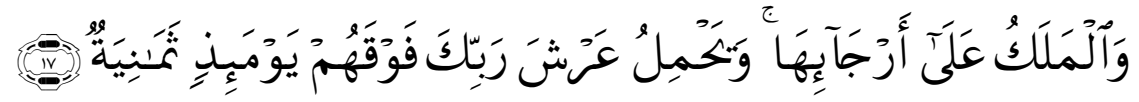

Artinya: “.. dan pada hari itu delapan orang malaikat menjunjung arsy Tuhanmu di atas kepala mereka" (QS. Al-Haqqah [69] : 17)

Menurut Ibn Sina, Arsy adalah planet ke-9 yang merupakan pusat planet-planet lain, sedangkan delapan malaikat adalah delapan planet penyangga yang berada di bawahnya. Ia menyatakan bahwa Arsy itu merupakan akhir wujud ciptaan jasmani. Kalangan antromorfosis yang menganut faham syari'at berpendapat bahwa Allah

\footnotetext{
${ }^{18}$ Juhaya S. Praja, Tafsir Hikmah, (Bandung : PT Remaja Rosda Karya, 2000) hal. 15

${ }^{19}$ Muhammad Husain al-Dzahabi, al-Tafsir wal Mufasirun, Juz II, hal. 309
} 
berada di atas Arsy tetapi bukan berarti ia berdiam di sana (hulul) sebagaimana juga pada filosof beranggapan bahwa akhir ciptaan yang bersifat jasmani adalah planet ke-9 tersebut, dan Tuhan berada di sana tapi bukan dalam artian berdiam. Selanjutnya mereka menjelaskan bahwa planet itu bergerak dengan jiawa. Gerak tersebut bersifat esensial dan tidak, gerak esensial dapat bersifat alamiah dan nafsiyah. Kemudian mereka jelaskan bahwa planet-planet tersebut tidak akan binasa dan tidak akan berubah sepanjang masa. Dalam syariat disebutkan bahwa malaikay itu hidup, tidak mati seperti layaknya manusia, maka jika dikatakan bahwa panet-planet itu mahluk hidup yang dapat berpikir dan mahluk hidup yang dapat berfikir disebut malaikat, maka panet-planet tersebut dinamakan malaikat ${ }^{20}$

\section{Al-Faraby (w. $339 \mathrm{H})$}

Karya tafsir Al-Farabi adalah 'Fushush al-Hikam'. Metode Tafsir yang digunakan oleh al-Farabi sama dengan Ibn Sina, yaitu sama-sama menilai Alquran dengan filsafat. Dalam kitabnya "Fushus al-Hikam" ia menafsirkan surah al-Hadid [57] ayat 3 dengan pendekatan filosofis:

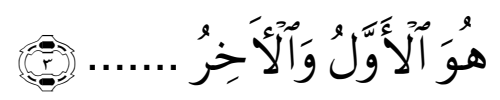

Artinya: “ Dialah yang awal dan yang akhir......"(QS. al-Hadid [57] : 3)

Dia menafsirkan ayat tersebut berdasarkan filsafat Plato tentang kekadiman alam, ia menyatakan bahwa wujud pertama ada dengan sendirinya. Setiap wujud yang lain berasa dari wujud yang pertama. Alam itu awal (qadim) karena kejadiannya paling dekat dengan wujud pertama. Sedangkan tafsir ia merupakan wujud yang terakhir ialah segala sesuatu yang diteliti, sebab-sebabnya akan berakhir pada-Nya. Dialah wujud terakhir karena Dia tujuan akhir yang hakiki dalam setiap proses. Dialah kerinduan utama karena itu Dia akhir dari segala tujuan. ${ }^{21}$

\section{Ibn Rusd}

Penafsiran Ibn Rusyd ini lebih cenderung pada perpaduan pemikiran filosof dan teori-teori yang ada dalam nas-nas Alquran. Dimana Ibn Rusyd mempertimbangkan dengan matang agar tidak terjebak dalam pemikiran filosof radikal yang mampu menjerumuskan alam pikiran kepada jalan yang menyesatkan.

Contoh tafsir Ibn Rusyd pada surah Hud [11] ayat 7:

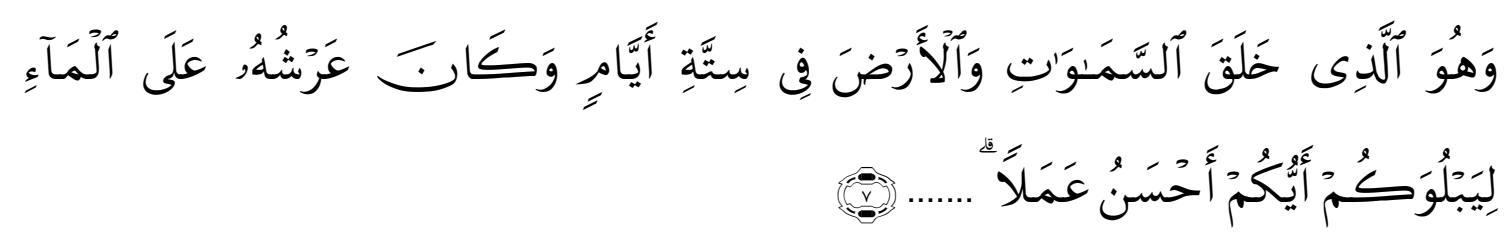

\footnotetext{
${ }^{20}$ Muhammad Husain Al Zahabi, Tafsir wa al-Mufassirun (Mesir: Dar al-Kuttab, 1976)., h. 426-427
}

${ }^{21}$ Al-Zahabi, Tafsir wa al-Mufassirun, h. 320 
Artinya: "Dan Dialah yang menciptakan langit dan bumi dalam enam hari dan tahtanya berada di atas air, agar Ia uji siapa diantara kamu yang paling baik amalnya”. (QS. Hud [11] : 7)

Menurutnya alam bukanlah diajadikan dari tiada tetapi dari sesuatu yang memang sudah ada. Sebelum ada wujud langit dan bumi telah ada wujud yang lain yaitu air yang diatasnya terdapat tahata kekuasaaan Tuhan. Sedangkan dalah alAnbiya ayat 30 dan Ibrahim ayat 47-48 disebutkan bahwa bumi dan langit pada umumnya berasal dari unsure yang sama, kemudian dipecah dari benda yang beraianan. Dengan demikian sebelum bumi dan langit telah ada benda lain yang dalam sebagian ayat diberi nama air, dan dalam ayat yang lain disebut uap. Uap dan air berdekatan selanjutnya langit dan bumi dijadikan dari uap atau air bukan dijadikan dari unsur yang tiada, dalam arti unsurnya bersifat kekal dari zaman yang qadim. ${ }^{22}$

\section{Thabathaba'i}

Karya tafsir Thabathaba'i adalah 'Tafsir Al-Mizan Fi Tafsir Alquran'. Salah satu Ayat Alquran yang ditafsirkan oleh Thabathaba'i dengan menggunakan metode filosofis ialah al-Baqarah [2] ayat 167 yang berbunyi:

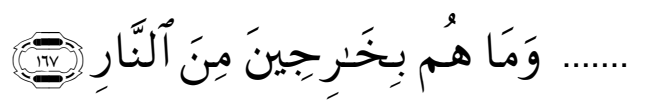

Artinya: “...Dan sekali-kali mereka tidak akan keluar dari api neraka”(QS.Al-Baqarah [2] : 167)

Menurutnya siksaan di neraka tidak akan kekal, karena Tuhan Maha Pengasih dan sangat luas, sehingga bagaimana mungkin Tuhan Yang Maha Pengasih akan menyiksa hambanya selamnaya. Alasan lainnya yang dikemukakan bahwa balas dendam terhadap perbuatan orang yang menganiaya hanyalah pekerjaan yang sia-sia. Sedang Allah Swt. tidak pernah berbuat dzalim terhadap hamba-Nya serta balas dendam, maka siksaan di neraka akan putus atau tidak kekal.

Pembahasan mengenai tafsir corak teologis filsafat ini, memberikan sebuah wawasan baru tentang perkembangan tafsir di abad pertengahan. Tafsir ini tentunya mempunyai segi positif dan negatif dalam perkembangannya. Dalam segi positif tent unya kita bisa tahu bahwa adanya tafsir yang bercorak filsafat ini adalah awal dari kontak antara dunia Islam dan dunia Barat dalam bidang ilmu pengetahuan. selain itu tafsir falsafi ini juga memberikan ruang yang lebih luas dalam bidang pemikiran dan penafsiran. Sebagaimana kita tahu bahwa selain corak filsafat ada juga corak fiqh, dimana keberadaannya menafsirkan Alquran dengan corak hukum.

Keberadaan tafsir corak filsafat ini juga menjadi "pintu gerbang" dari kemajuan pemikiran di Islam. sebagaimana yang telah kita pelajari juga bahwa munculnya tafsir falsafi dan para tokohnya bebarengan dengan masa kegelapan di

${ }^{22}$ Harun Nasution, Filsafat dan Mistisme dalam Islam, (Jakarta: Bulan Bintang, t.th)., h. 50 
dunia Barat, sehingga ilmu pengetahuan di Barat pada saat itu mengalami stagnasi sedangkan perkembangan ilmu pengetahuan di dunia Islam mulai berseri. Hal ini tentunya menjadi catatan sejarah tersendiri dimana peran para filosof muslim yang mengisi perkembangan pengetahuan para masa itu.

Sedangkan kekurangan pada corak filsafat ini adalah tafsir falsafi cenderung membangun proposisi universal hanya berdasarkan logika dan karena peranan logika begitu mendominasi, maka metode ini kurang memperhatikan aspek historititas kitab suci. Namun begitu, ada positifnya yaitu kemampuan membangun abtraksi dan proposisi makna-makna latent (tersembunyi) yang diangkat dari teks kitab suci untuk dikomunikasikan lebih luas lagi kepada masyarakat tanpa hambatan budaya dan bahasa. $^{23}$

Dari pemahaman tersebut tidak terlalu berlebihan kiranya kalau kita mengharapkan nantinya terwujudnya tafsir falsafi yang ideal. Sebuah tafsir falsafi yang kontemporer yang tidak hanya berlandaskan interpretasi pada kekuatan logika tetapi juga memberikan perhatian pada realitas sejarah yang mengiringinya. Sebab pada prinsipnya teks Alquran tidak bisa lepas dari struktur historis dan konteks sosiokultural di mana ia diturunkan. Dengan demikian, akan lahir tafsir-tafsir filosofis yang logis dan proporsional, tidak spekulatif dan dilebih-lebihkan. Dan harapan itu tidak berlebihan karena di samping memang kita belum menemukan tafsir yang secara utuh mengunakan pendekatan filosofis, kalau pun ada itu hanya terbatas pada beberapa ayat yang ditemukan pada buku-buku karangan mereka.

\section{Hermeneutika Alquran: Corak Tafsir Falsafi Modern}

Akhir-akhir ini di kalangan kaum muslimin -terutama kaum modernis- telah banyak memanfaatkan Hermeneutika sebagai salah satu instrumen untuk menggali isi dan kandungan Alquran. Penggunaan ilmu tersebut dalam penafsiran Alquran ada yang menempatkannya sebagaikomplemen dan ada pula yang menempatkannya sebagai sublemen.

Penggunaan hermeneutika dalam dunia penafsiran Alquran adalah hal baru yang belum pernah dilakukan oleh para mufassir terdahulu. Dalam tradisi keilmuwan Islam telah dikenal ilmu tafsir yang berfungsi untuk menafsirkan Alquran, sehingga ilmu ini dianggap telah mapan dalam bidangnya. Dari segi epistemologi dan metodologi ilmu ini telah diakui mampu mengembankan tugasnya untuk menggali kandungan Alquran.

Jika metode tafsir selama ini menempatkan teks sebagai satu-sat unya area kajian, maka sekarang saatnyalah unsur empiris, sosiologi, antropologi, filsafat ilmu, sejarah dan sebagainya yang terlibat dalam pembentukan teks itu diekplorasi. Faktor-faktor dalam rekontruksi inilah yang sangat kental danmenjadi bahasan pentinga dalam kajian hermeneuika selama ini.Penafsiran Alquran dengan menggunakan metode hermeneutikabelakangan ini mulai digemarioleh sebagian kalangan pemikir modernis,

${ }^{23}$ Komaruddin Hidayat, Memahami Bahasa Agama, sebuah kajian heuremetik, (Jakarta: Paramadina, 1996)., h. 215 
neomodernis,atau post-modernis. ${ }^{24}$ Mereka menganggap bahwa metode ini sangat layak untuk menjawab isu kontemporer saat ini, karena mereka menilai bahwa ilmu tafsir yang selama ini dijadikan acuan dalam memahami Alquran ternyata memiliki berbagai keterbatasan. Sehingga metode ini menjadi salah satu alternatif sebagai pengganti perangkat keilmuan yang selama ini dianggap bukan hanya tidak memadai, namun juga tidak "tahan banting" terhadap tantangan zaman. ${ }^{25}$

\section{Definisi Hermeneutika}

Secara etimologis, kata hermeneutika diambil dari bahasa Yunani, yakni hermeneuein, yang berarti menjelaskan. Kata itu kemudian diserap ke dalam bahasa Jerman yaitu hermeneutik dan hermeneutics dalam bahasa Inggris. Hermeneutika adalah seni praktis, yang digunakan dalam hal-hal seperti berceramah, menafsirkan bahasa-bahasa lain, menerangkan da menjelaskan teks-teks, dan sebagai dasar dari semua itu karena ia merupaka seni memahami, sebuah seni yang secara khusus dibutuhkan ketika makna sesuatu teks itu tidak jelas. ${ }^{26}$

Hermeneutika adalah alat-alat yang digunakan terhadap teks dalam menganalisis dan memahami maksudnya serta menampakkan nilai yang dikandungnya. Secara singkatnya adalah cara kerja yang harus ditempuh oleh siapapun yang hendak memahami suatu teks baik yang terlihat nyata dari teksnya maupun kabur bahkan tersembunyi akibat perjalanan sejarah atau pengaruh ideologi dan kepercayaan. ${ }^{27}$

Hermeneutika dalam arti luas adalah bidang ilmu yang membahas praktik penafsiran, metode-metode, prinsip-prinsip dan filsafat penafsiran (bidang ilmu yang mengalami perkembangan pesat di Dunia Barat). ${ }^{28}$ Tokoh yang memberikan definisi hermeneutika adalah menurut Friedrich Schleiermacher, hermeneutika yaitu seni memahami secara benar bahasa orang lain, khususnya bahasa tulis. Bagi Gadamer, hermeneutika adalah seni menafsirkan dan juga sebagai disiplin yang membahas aspek metodis yang secara teoritis yang dapat menjustifikasi aktivitas penafsiran. Sedangkan menurut Franz-Peter Burkard, hermeneutika adalah seni menafsirkan teks dan refleksi teoritis tentang metode dan syarat pemahaman. ${ }^{29}$ Sedangkan keberagaman dan kebertingkatan definisi hermeneutika dipaparkan oleh Ben Vedder yaitu:

a. Hermeneuse yaitu penjelasan atau interpretasi sebuah teks, karya seni atau perilaku seseorang

b. Hermeneutik yaitu pembahasan tentang regulasi, aturan, metode, strategi, langkah penafsiran yang menguak kesatuan makna teks sesuai dengan kebenaran dan keobyektifan. ${ }^{30}$

${ }^{24}$ Diataranya Fazlur Rahman, Muhammad Arkon, al-Jabiri, Hasan Hanafi, Nasr Hamid Abu Zeid, Farid Essac, Prof. Dr. Amin Abdullah, dan Prof. Dr. Phil. Nur Kholis Setiawan.

${ }^{25}$ Ahmad Izzan, Metodologi Ilmu Tafsir(Bandung: Tafakur, 2009), h.211

${ }^{26}$ Syafa' atun Al-Mirzanah, Sahiron Syamsuddin, Upaya Hermeneutika dalam Kajian Qur'an dan Hadis Teori dan Aplikas Buku Dua Tradisi Barat, (Yogyakarta: Lembaga Penelitian UIN Sunan Kalijaga Yogyakarta), h., 28.

${ }^{27}$ M. Quraish Shihab. Kaidah Tafsir, (Tangerang: Lentera hati, 2012),h.401.

${ }^{28}$ Ibid.,Syafa'atun Al-Mirzanah, Sahiron Syamsuddin, Upaya Hermeneutika..., h.vii.

${ }^{29}$ Ibid.,Syafa' atun Al-Mirzanah, Sahiron Syamsuddin, Upaya Hermeneutika..., h. 29.

${ }^{30}$ Ibid., h.0-31. 
c. Philosophisce Hermeneutik adalah hemeneutika filosofis yang tidak lagi membicarakan metode eksegetik tertentu sebagai obyek pembahasan inti, melainkan hal yang terkait dengan kondisi kemungkinan yang mana dengan hal itulah seseorang dapat memahami dan menafsirkan sebuah teks, simbol atau perilaku.

d. Hermeneutische Philosophie (filsafat hermeneutis) adalah bagian dari pemikiran filsafat yang mencoba menjawab problem kehidupan manusia dengan cara menafsirkan apa yang diterima oleh manusia dari sejarah dan tradisi. ${ }^{31}$

\section{Sejarah Munculnya Hermeneutika Sebagai Teori Interpretasi Teks}

Hermeneutika dalam tradisi Barat, pada awalnya, merupakan bagian dari ilmu filologi, ilmu yang membahas tentang asal-usul bahasa dan teks. Oleh karena itu, historigrafi merupakan klien hermeneutika yang paling setia. Mulai abad ke-16, hermeneutika mengalami perkembangan dan memperoleh perhatian yang lebih akademis dan serius ketika kalangan ilmuwan gereja di eropa terlibat diskusi dan debat mengenai autentisitas Bibel. Mereka ingin memperoleh kejelasan serta pemahaman yang benar mengenai kandungan Bibel yang dalam berbagai hal, dianggap bertentangan.

Istilah Hermeneutika sendiri, secara historits muncul pertama kali dalam karya Johan Konrad Dannhauer, seorang teolog Jerman, yang berjudul Hermeneutica Sacra, Sive Methodeus Exponen darums Sacrarum Litterarum yang ditulis pada tahun 1654. Sebagai teolog, hermeneutika dalam buku ini masih terbatas pada pembahasan metode menafsirkan teks-teks Bibel.

Memasuki akhir abad ke-18, Hermeneutika mulai dirasakan sebagai teman dan sekaligus tantangan ilmu sosial, utamanya sejarah dan sosiologi, karena Hermeneutika mulai berbicara dan menggugat metode dan konsep ilmu sosial pada umumnya. Khususnya dalam ilmu sejarah, karena yang menjadi objek kajian adalah pemahaman tentang makna dan pesan yang terkandung dalam sebuah teks, yang variabelnya meliputi pengarang, proses penulisan, dan karya tulis. ${ }^{32}$

Hermeneutika tidak muncul secara tiba-tiba sebagai cabang disiplin ilmu filsafat dalam khazanah ilmu pengetahuan, tetapi merupakan suatu subdisiplin teologi yang sudah muncul sejak awal dalam sejarah peradaban manusia yang mencakup kajian metodologis tentang autentikasi dan penafsiran teks. Namun pada perkembangan berikutnya berkembang menjadi masalah penafsiran secara menyeluruh. Sebab tekstualitas yang menjadi arena beroperasinya kerja hermeneutika telah diperluas maknanya, terutama oleh Schlermacher. Teks bukan lagi semata merujuk pada pengertian teks ajaran agama, tetapi juga mencakup teks lain.

Kemudian,Diltheymengembangkandisiplinhermeneu-tikasecara lebih dalam dengan menjadikannya sebagai metodologis bagi ilmu-ilmu kemanusiaan. Dalam hal ini, merumuskan metode verstehen (memahami) yang spesifik bagi ilmu sosial dan

\footnotetext{
${ }^{31}$ Ibid., h. 32.

${ }^{32}$ KomaruddinHidayat, MemahamiBahasaAgamaSebuahKajian Hermeneutika, (Bandung: Mizan, 2011), h. 212
} 
budaya yang berbeda dengan erkeleren (menjelaskan) yang lazim dalam ilmu-ilmu alam. Dalam perkembangan mutakhir pasca Dilthey, hermeneutika mengalami pergeseran penting dari fungsinya sebagai metode pemahaman dan pencarian kebenaran yang merepresentasikan cara kerja epistomologi kepada kecenderungan baru sebagai sebuah filsafat dengan titik penekanan pada aspek ontologis dengan pemahaman. $^{33}$

Selanjutnya di tangan pemikir Heidegger dan Gadamer, Hemeneutika mengalami perubahan kecenderungan ke arah pembahasan yang lebih filosofis. Inilah yang membuat hermeneutika semula direfleksikan sebagai sebuah epistemologi pemahaman yang lebih dipertajam lagi pembahasannya secara lebih mendalam dari sisi ontologisnya.

Menurut Mauludin sebagaimana dikutip Mudjia Rahardjo, pada awal perkembangannya, sekitar awal abad pertengahan, hermeneutika digagas sebagai praksis murni yang menggarap tema keagamaan. Pada tahapan ini, lebih merupakan piranti penafsir ayat suci, khususnya Bibel. Perkembangan tahap kedua dari gagasan hermeneutika tampak dari semakin dibutuhkannya metodologi, tidak hanya untuk menggarap tema-tema keagamaan, tetapi juga tema kemanusiaan.

Perkembangan terakhir, hermeneutika dipahami sebagai sebuah teori, metodologi, dan praksis penafsiran, yang digerakkan ke arah penangkapan makna dari sebuah teks atau sebuah analog teks, yang secara temporal atau kultural berjarak jauh, atau dikaburkan oleh ideologi dan kesadaran palsu. Tahap ini, hermeneutika lantas beranjak pada pemikiran reflektif dan spekulatif terkait dengan upaya manusia memahami proses penafsiran. Dalam bahasa Gadamer, hermeneutika dipandang sebagai usaha filosofis untuk mempertanggungjawabkan pemahaman sebagai proses ontologis dalam manusia. ${ }^{34}$

\section{Lingkaran HermeneutikadalamInterpretasi Teks}

Prinsip dasar hermeneutika yang diajukan Schleimarcher adalah bahwa teks merupakan ekspresi perangkat linguistic yang mentransformasikan ide pengarang kepada pembaca. Artinya, dalam setiap teks, ada dua aspek yang perlu diperhatikan,yaitu aspek linguistik yang berupa bahasa dan kelengkapannya (sisi obyektif) dan aspek psikis yang berupa ide subyektif pengarang (sisi subyektif). Hubungan antara kedua aspek ini, menurut Schleiermacher adalah hubungan dialektis. Maksudnya, setiap kali teks muncul dalam suatu waktu, maka ia akan menjadi samarsamar bagi pembaca berikutnya. Oleh karena itu, pembaca menjadi lebih dekat kepada kesalahpahaman dari pada pemahaman yang sebenarnya. ${ }^{35}$ Oleh karena itu pula,untuk mengakses makna sebuah teks, pembaca (baca: penafsir) membutuhkan dua

\footnotetext{
${ }^{33}$ Ilham B. Saenong, Hermeneutika Pembebasan, (Bandung: Teraju, 2002), h. 27

${ }^{34}$ MudjiaRaharjo, Dasar-dasarHermeneutikaantara Intensionalisme dan Gadamerian, (Jogjakarta: ArRuz Media), 2012, h. 27

${ }^{35}$ Nasr Hâmid Abû Zayd, Hermeneutika Inklusif: Mengatasi Problematika dan Cara-cara Pentakwilan atas Diskursus Keagamaan, terj. Muhammad Mansur \& Khoiron Nahdliyin (Yogyakarta: PT. LKIS, 2004), h. $15-16$
} 
kompetensi, yakni kompetensi linguistik dan kempetensi dalam mengakses alam kemanusian.

Secara prosedural, langkah kerja hermeneutika juga menggarap tiga wilayah, yaitu teks, konteks dan kontekstualisasi. Untuk memperoleh pemahaman yang tepat terhadap suatu teks, maka pengetahuan keberadaan konteks di seputar teks tersebut adalah suatu hal yang penting. Pengetahuan terhadap konteks merupakan usaha melacak bagaimana teks yang dibaca tersebut dimaknai dan dipahami pengarangnya dan juga dalam kondisi apa dan untuk tujuan apa teks tersebut muncul atau dimunculkan. Selanjutnya adalah upaya kontekstualisasi, yaitu berusaha agar pemahaman dan pemaknaan teks yang diperoleh dengan menimbang konteks tersebut masih dapat fungsional dan operasional bagi pembaca sesuai dengan konteksnya saat ini.

Dalam kajian hermeneutika yang perlu diperhatikan adalah triadic structure; teks (text), penulis atau pengarang (author), dan pembaca (reader). Dari lingkaran hermeneutika tersebut, muncul sebuah pertanyaan bagaimana cara merumuskan relasi yang tepat antara tiga aspek tersebut.

Kurang lebih dua puluh tahun lalu, terjadi perdebatan serius tentang dinamika antara pengarang, teks dan pembaca. Perdebatan tersebut berkaitan dengan problem tentang apa atau siapa yang harus menentukan makna dalam sebuah penafsiran ${ }^{36}$ Ada tiga teori utama berkaitan dengan hal tersebut. Pertama, teori yang berpusat pada penulis atau pengarang. Teori ini berasumsi bahwa makna adalah arti yang ditentukan oleh penulis atau pengarang atau setidaknya oleh upaya pemahaman terhadap maksud pengarang. Pengarang sebuah teks tampaknya telah memformulasikan maksudnya ketika ia membentuk sebuah teks, dan pembaca berusaha memahami maksud pengarang atau berusaha memahaminya. ${ }^{37}$ Pandangan ini ketika dikaitkan dengan pemahaman teks keagamaan (Alquran dan al-Ḥadîth) akan melahirkan pendekatan otoritatif keagamaan, yakni bahwa yang paling mengetahui "maksud penulis atau pengarang" adalah Rasulullah, kemudian para sahabat, tabi'in, dan selanjutnya para ulama' yang notabene sebagai pewaris para Nabi. Pembaca akan sulit mengetahui" maksud penulis atau pengarang" itu tanpa bantuan otoritas keagamaan tersebut. ${ }^{38}$ Kedua, yaitu teori yang berpusat pada peranan teks. Asumsinya adalah bahwa makna suatu teks itu ada pada teks itu sendiri. Maksud penulis atau pengarang tidaklah terlalu penting, karena begitu teks lahir, maka ia telah terlepas dari penulisnya. ${ }^{39}$ Artinya,teks memiliki realitas dan integritasnya sendiri, dan realitas serta integritas teks itu berhak untuk dipatuhi. ${ }^{40}$ Ketiga, yaitu teori yang berpusat pada pembaca. Asumsinya bahwa makna

\footnotetext{
${ }^{36}$ Khaled Abou El Fadl, Speaking in God's Name: Islamic Law, Authority, and Women(Inggris: Oneworld, 2003), h.120

${ }^{37}$ Ibid., h. 121.

${ }^{38}$ Moch Nur Ichwan, "Al-Qur"ean sebagai Teks (Teori Teks dalam Hermeneutika Qur"anNasr Hâmid Abû Zayd" dalam Abdul Mustaqim dan Sahiron Syamsuddin (eds.), StudiAl-Qur'an Kontemporer: Wacana Baru Berbagai Metodologi Tafsir(Yogyakarta: Tiara Wacana,2002), h.162-163.

${ }^{39}$ Ibid.

${ }^{40}$ El Fadl, Speaking in God's, h. 121.
} 
suatu teks adalah apa yang mampu diterima dan diproduksi oleh pembacanya dengan segala horizon pengetahuan dan pengalaman hidupnya. Yang terpenting di sini adalah bagaimanateks itu berfungsi dalam suatu masyarakat pembacanya. ${ }^{41}$

Berkaitan dengan hal tersebut,Nasr Hâmid Abû Zayd tidak setuju dengan pandangan bahwa makna itu digagas oleh pembaca sendiri. Dia mengatakan bahwa dalam proses penerjemahan, teks bukanlah obyek yang diam yang dapat dibawa kedalam petunjuk oleh pembaca yang aktif. Hubungan antara teks dan pembaca bukanlah hubungan ikhda' (kekuatan teks untuk menyampaikan kepada pembaca) dan khudû' (kepatuhan pembaca pada teks). Selanjutnya, ia menyatakan bahwa hubungan antara teks dan pembaca adalah jadalîyah (relasi dialogis). ${ }^{42}$ Ini berarti bahwa pembaca seharusnya mengkaji dan menelaah ulang ketika berhasil menangkap makna teks, karena makna yang ditangkap senantiasa dapat bergeser dan berubah. Dialektika antar makna yang dapat ditangkap itulah yang pada akhirnya berperan mewujudkan holistika pemahaman.

\section{Hermeneutika dan Ilmu Tafsir Alquran}

Peran hermeneutika dalam menafsirkan berbagai kajian keilmuan khususnya kitab suci amatlah besar. Sebagai alternatif baru dalam metodologi dalam mengkaji kitab suci, keberadaan Hermeneutika tidak bisa dihindarkan dari dunia kitab suci Alquran. Bahkan ilmu tafsir kontemporer yang menawarkan hermeneutika berjamur sebagai variabel metode pemahaman Alquran menunjukkan bahwa daya tarik hermeneutika amat luar biasa. Hasan hanafi sebagaimana dikutip Fahruddin Faiz menyatakan hermeneutik tidak sekedar ilmu interpretasi atau teori pemahaman, tetapi juga berarti ilmu yang menjelaskan penerimaan wahyu sejak dari tingkat perkataan sampai ke tingkat dunia. Ilmu tentang proses wahyu dari huruf sampai kenyataan, dari logos sampai praksis dan juga transformasi wahyu dari pikiran Tuhan kepada kehidupan manusia. ${ }^{43}$

Sebenarnya istilah khusus dalam dunia keilmuan islam guna melaksanakan interpretasi adalah tafsir, yang berasal dalam bahasa Arab fassara. Digunakan secara teknis dalam pengertian mencari keterangan di kalangan orang Islam dari abad ke-5 hingga sekarang.

Dewasa ini banyak pemerhati Alquran melakukan kritik historis dan linguistik, yang menjadi ciri khas hermeneutika. Nashr Hamid Abu Zayd sebagaimana dikutip Sahiron Syamsudin, menyatakan bahwa Alquran dari segi linguistik ia merupakan teks bahasa yang secara historis terbentuk dalam ruang waktu. Watak tekstual qur'an merupakan sisi penting untuk dipahami. Ada 3 hal yang menunjukkan watak tekstual qur'an:

\footnotetext{
${ }^{41}$ Ichwan, "Al-Qur"ean sebagai Teks", h. 163.

${ }^{42}$ Nasr Hamid Abû Zayd, Ishkaliyyât al Qirâ'ah wa Alîyat al- Ta’wîl (Beirut: al-Markas al- 'Arabî alIslâmî,t.th), h. 17

${ }^{43}$ FahruddinFaiz, HermeneutikaAlquranTema-TemaKontroversial,(Yogyakarta: ElSaq Press, 2005), h. 112
} 
1. Alquran merupakan risalah wahyu dimana pewahyuannya merupakan proses komunikasi yang melibatkan pengirim (Allah), penerima (Muhammad), perantara (Jibril) dan kode komunikasi (bahasa arab).

2. Antara surat serta ayatnya yang berbeda dengan kronologis turunnya wahyu qur'an.

3. Alquran terdapat ayat-ayat muhkamat dan mutasyabihat, menjadikan teks lebih dinamis. ${ }^{44}$

Dalam dataran penafsiran klasik keagamaan yang berkembang dalam tradisi klasik, ada perbedaan yang tegas antara "tafsir bi al-ma'tsur" dan "tafsir bi alra'yi" atau ta'wil. Karena tafsir bi al-ma'tsur, berupaya menggali makna dengan mengumpulkan dalil melalui jalur historis dan linguistik yang membantu memahami secara objektif, melalui pemisalan linguistik yang terkandung dalam teks dan pemahaman kehadiran teks itu sendiri. Contohnya ialah Ahli sunnah dan generasi awal Islam.

Sementara tafsir bi al-ra'yi dipandang sebagai tafsir yang tidak objektif. Karena penafsirannya tidak dimulai melalui realitas historis dan linguistik, tetapi justru dimulai dari prapemahaman dan penafsir yang berusaha mencari legitimasi dalam Alquran bagi prapemahamannya itu. Teks Alquran hanya untuk ditempelkan pada imaji yang telah ia punyai sebelumnya. Contohnya para filosof, Mu'tazilah, Syi'ah dan Sufi.

Kelemahan Kitab-kitab tafsir bi al-ma'tsurtidak bisa dilepaskan dari berbagai kreatifitas penafsiran, sedangkan karya tafsir bi al-ra'yitidak menutup diri pada realitas historis dan linguistik yang berkaitan dengan teks. Dalam konteks ini, problem penafsiran metafisik belum dijangkau oleh para ulama klasik secara khusus, walaupun dilakukan penafsiran, problemnya ialah Bagaimana mungkin seorang penafsir mencapai pada makna teks Alquran secara "objektif"? baik tafsir bi alma'tsur dan tafsir bi al-ra'yi tidak bisa memberi jawaban pada hal itu. Akhirnya penganut ta'wil lebih bebas dalam memahami dan melakukan kreatifitas, sedangkan ulama klasik masih berpegang pada kapasitas pemahaman objektif yang lazim digunakan. ${ }^{45}$

Demikianlah, sejak awal hermeneutika berurusan dengan tugas menerangkan kata-kata dan teks yang dirasakan asing oleh masyarakat (alien speech), entah karena datang dari Tuhan yang berbicara dengan bahasa "langit" ataupun yang datang dari generasi terdahulu yang hidup dalam tradisi dan bahasa yang "asing". Persoalan penafsiran dan pemahaman ini semakin fenomenal dengan hadirnya masyarakat global yang ditandai dengan pluralitas agama, kebudayaan dan bahasa.

\section{Penutup}

Bertolak dari pembahasan di atas, tampak jelas bahwa tafsir falsafi telah memberikan sebuah wawasan baru tentang perkembangan tafsir di abad pertengahan.

\footnotetext{
${ }^{44}$ SahironSyamsudin, HermeneutikaAlquranMazhabYogya, (Yogyakarta: Islamika, 2003), h.108

${ }^{45}$ Nashr Hamid Abu Zayd, Alquran, Hermeneutik dan Kekuasaan,(Bandung: RqiS, 2003), h. 36
} 
Keberadaan tafsir corak filsafat ini juga menjadi "pintu gerbang" dari kemajuan pemikiran di Islam. sebagaimana yang telah kita pelajari juga bahwa munculnya tafsir falsafi dan para tokohnya bebarengan dengan masa kegelapan di dunia Barat, sehingga ilmu pengetahuan di Barat pada saat itu mengalami stagnasi sedangkan perkembangan ilmu pengetahuan di dunia Islam mulai berseri. Hal ini tentunya menjadi catatan sejarah tersendiri dimana peran para filosof muslim yang mengisi perkembangan pengetahuan para masa itu.

Sampai abad modern ini, muncullah metode penafsiran baru dengan pendekatan filsafat yaitu hermeneutik Alquran. Terlepas dari sikap pro dan kontra, hermeneutika mempunyai tujuan yang luhur, yaitu menjelaskan makna dan tujuan yang dikandung oleh teks, karena adanya jarak, baik bahasa, waktu, geografis dan budaya. Dalam mengkaji sebuah teks dengan metode hermeneutika terdapat lingkaran hermeneutika yang tidak boleh dikesampingkan salah satunya, yaitu teks (text), penulis atau pengarang (outhor), dan pembaca (reader) dengan wilayah garapan teks, konteks dan kontekstualisasi

Bila hermeneutik dipresepsi akan memperkokoh konstruk pemikiran tentang metode penafsiran selama ini, maka ia adalah anugerah dan pintu untuknya sangat terbuka. Namun jika tidak, maka malapetaka yang akan didapat. Di sisi lain, untuk mencapai penafsiran yang pariurna, ilmu tafsir mau tidak mau akan memcoba "berbagi" dengan hermenutika untuk memasuk bidang kajiannya. 


\section{DAFTAR PUSTAKA}

Abû Zayd, Nasr Hâmid, Hermeneutika Inklusif: Mengatasi Problematika dan Caracara Pentakwilan atas Diskursus Keagamaan, terj.Muhammad Mansur \& Khoiron Nahdliyin. Yogyakarta: PT.LKIS, 2004

'Arabî al-Islâmî, t.th

IshkaliyyâtalQirâ'ahwaAlîyatal-Ta'wîl. Beirut:al-Markasal, Alquran, Hermeneutik dan Kekuasaan. Bandung: RqiS, 2003

Al-Dzahabi, Muhammad Husein, Kitâb al-Tafsîr wa al-Mufassirûn. Beirut: Dar al-Fikr, 1995, Juz III

Al-Farmawi, Abdul Hayy, Metode Tafsir Maudhu'i Dan Cara Perepannya, Penerjemah, Suryan A. Jamrah. Jakarta: PT Raja Grafindo Persada, 1994

Al-Gazāli, Imam, al-Munqīd min al-Dalāl, Qahirah: Maktabah al-Islamiyah, $1303 \mathrm{H}$ , Tahāfut al-Falāsifah (kerancuan para filosof), diterjemahkan Ahmadie Thaha. Jakarta: Pustaka Panjimas, 1986

Al-Majlis al-A'la li al-Syuuni al-Islamiyah, al-Mausuah Alquraniyah al-Mutakhossisah, Kairo: Wazir al-Auqaf, 2003

Al-Mirzanah, Syafa'atun, dan Syamsuddin, Sahiron, Upaya Hermeneutika dalam Kajian Qur'an dan Hadis Teori dan Aplikas Buku Dua Tradisi Barat. Yogyakarta: Lembaga Penelitian UIN Sunan Kalijaga Yogyakarta.

Al-Żahabi, Muhammad Husain, Tafsīr wa al-Mufassirūn Mesir: Dar al-Kuttab, 1976

At-Thaba'-Thaba'i, Muhammad Hussain, al-Mizan fi Tafsir Alquran. Bairut: $\mathrm{Mu}$,assisah al-Alamy Li al Mathbu'at, t.t

El- Fadl,KhaledAbou, SpeakinginGod'sName:IslamicLaw,Authority, andWomen. Inggris:Oneworld,2003

Eliade, Mircea, The Encyclopedia of Religion, New York: Macmillan, 1993

Faiz, Fahruddin, Hermeneutika Alquran Tema-Tema Kontroversial. Yogyakarta: ElSaq Press, 2005

Hamdi, Mahmud, Al-Mausu'ah Alquraniah al Mutakhossishoh, Kairo: Kementrian wakaf, 2003

Hidayat, Komaruddin, MemahamiBahasaAgamaSebuahKajian HermeneutikaBandung: Mizan, 2011

Ichwan,MochNur,“Al-Qur'an sebagai Teks (Teori Teks dalam Hermeneutika Qur'an Nasr Hâmid Abû Zayd" dalam Abdul Mustaqim dan Sahiron Syamsuddin (eds.),Studi Al-Qur'an Kontemporer: Wacana Baru Berbagai Metodologi Tafsir, Yogyakarta: TiaraWacana,2002.

Izzan, Ahmad, Metodologi Ilmu Tafsir. Bandung: Tafakur, 2009

Juhaya S. Praja, Tafsir Hikmah, Bandung : PT Remaja Rosda Karya, 2000 
Muliono R, Slamet, "Hermeneutika Alquran: Antara Pemaknaan Tekstual dan Kontekstual", dalam, Ulumuna, Volume XIV Nomor 1 Juni 2010

Mustaqim, Abdul, Dinamika Sejarah Tafsir Al-Quran. Yogyakarta: Adab Press, 2012

Nasution, Harun, Filsafat dan Mistisme dalam Islam. Jakarta: Bulan Bintang, t.th

Raharjo, Mudjia, Dasar-dasarHermeneutikaantara Intensionalisme dan Gadamerian. Jogjakarta: Ar-Ruz Media, 2012

Saenong, Ilham B., Hermeneutika Pembebasan,Bandung: Teraju, 2002

Shihab, Quraish, dkk, Sejarah dan Ulum Al Qur'an. Jakarta: Pustaka Firdaus, 1999

Shihab. M. Quraish, Kaidah Tafsir. Tangerang: Lentera hati, 2012.

Syamsudin, Sahiron, Hermeneutika Alquran Mazhab Yogya,Yogyakarta: Islamika, 2003 